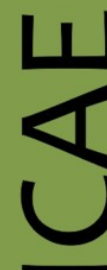

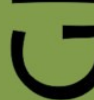

ex Instituto Archaeologico Universitatis de Rolando Eötvös nominatae

O

$\overrightarrow{0}$

山

$\leftarrow$

I

$\cup$

ه

$\leftarrow$

u

Ш

Z

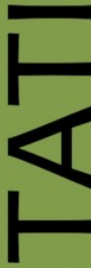

œ

ш

n

n

$\varnothing$
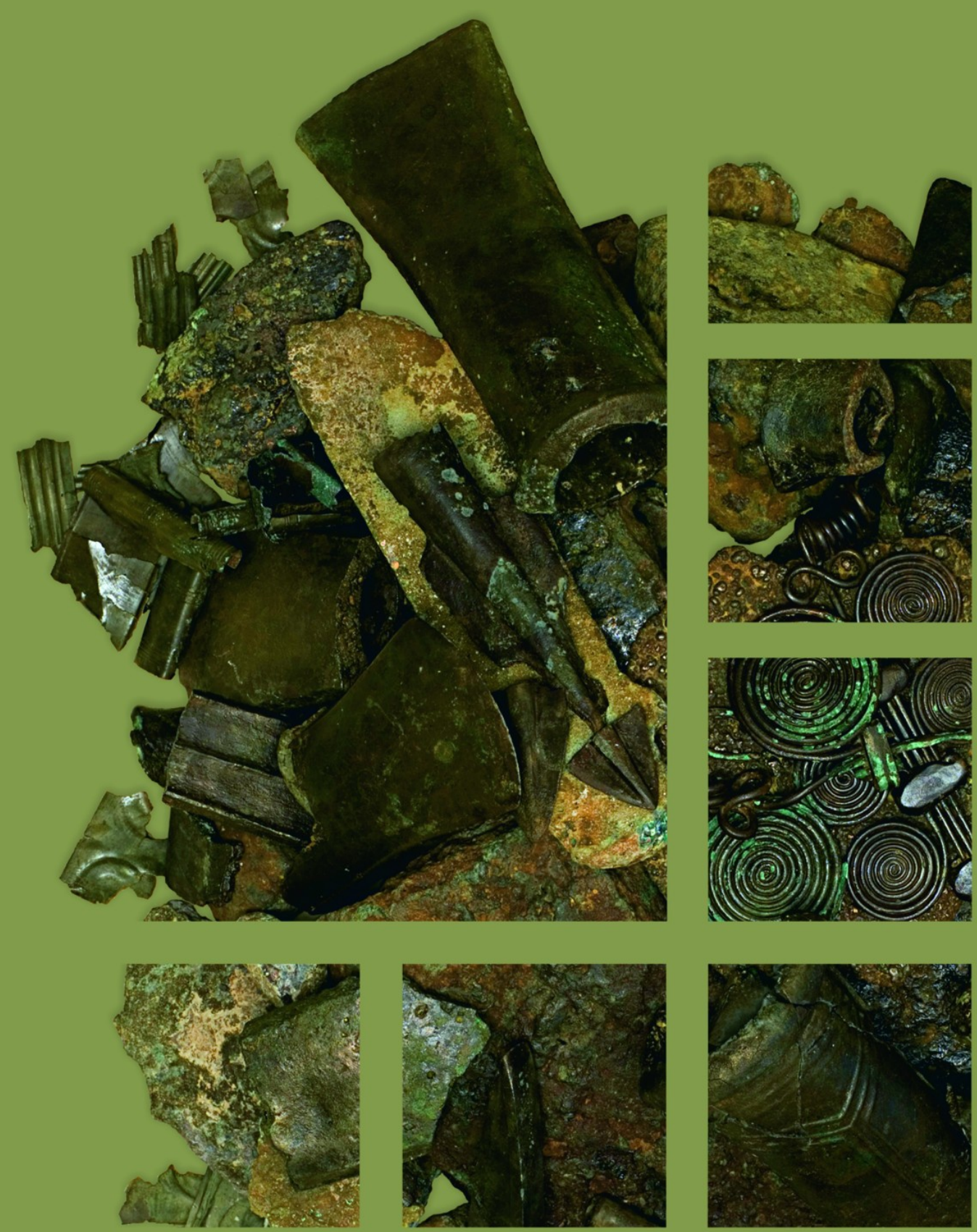


\section{Dissertationes Archaeologicae ex Instituto Archaeologico}

Universitatis de Rolando Eötvös nominatae Ser. 3. No. 2.

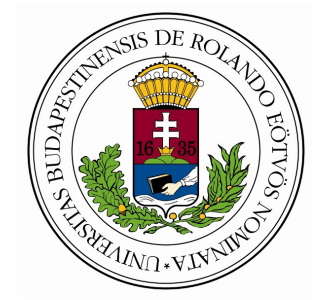

Budapest 2014 
Dissertationes Archaeologicae ex Instituto Archaeologico Universitatis de Rolando Eötvös nominatae

Ser. 3. No. 2.

Editor-in-chief:

DÁvid BARTus

Editorial board:

LÁsZló BARTOSIEWICZ

LÁSZLÓ BORHY

IsTVÁN FELD

GÁBOR KALLA

PÁL RACZKY

MiKLÓs SzABÓ

TIVADAR VIDA

Technical editors:

DÁvid BARTus

GÁBOR VÁCZI

ANDRÁs BÖDŐCS

DÁNIEL SZABÓ

Proofreading:

SZILVIA SzÖLLősI

Available online at http://dissarch.elte.hu Contact: dissarch@btk.elte.hu

$$
\begin{aligned}
& \text { PUBLIC } \\
& \text { KNOWLEDGE } \\
& \text { PROJECT }
\end{aligned}
$$

(c) Eötvös Loránd University, Institute of Archaeological Sciences

Budapest 2014 


\section{Contents}

\section{SElected PAPERS OF THE XI. Hungarian CONFERENCE on Classical Studies}

Ferenc BARNA

Venus mit Waffen. Die Darstellungen und die Rolle der Göttin in der Münzpropaganda

der Zeit der Soldatenkaiser (235-284 n. Chr.)

Dénes GABLER

A belsó vámok szerepe a rajnai és a dunai provinciák importált kerámiaspektrumában

Lajos MATHÉDESZ

Római bélyeges téglák a komáromi Duna Menti Múzeum gyújteményében

Katalin OtTOMÁNYI

Újabb római vicusok Aquincum territoriumán

Eszter SÜVEGH

Hellenistic grotesque terracotta figurines. Problems of iconographical interpretation

András SzABó

Some notes on the rings with sacred inscriptions from Pannonia

István VIDA

The coinage of Flavia Maxima Helena

\section{Articles}

Gábor TARBAY

Late Bronze Age depot from the foothills of the Pilis Mountains

Csilla SÁRó

Roman brooches from Paks-Gyapa - Rosti-puszta

András BöDőcs - Gábor KovÁcs - Krisztián ANDERKó

The impact of the roman agriculture on the territory of Savaria

Lajos JuHÁsz

Two new Roman bronzes with Suebian nodus from Brigetio

\section{FIELD REPORTS}

Zsolt MESTER - Norbert FARAGó - Attila KirÁLy

The first in situ Old Stone Age assemblage from the Rába Valley, Northwestern Hungary

Pál RACZky - Alexandra ANDERs - Norbert FARAgó - Gábor MÁRKus

Short report on the 2014 excavations at Polgár-Csőszhalom 
Preliminary Report on the first season of fieldwork in Berettyóúffalu-Szilhalom

Márton SzILÁgyi - András FüZESI - Attila VIRÁG - Mihály GASPARIK

A Palaeolithic mammoth bone deposit and a Late Copper Age Baden settlement and enclosure

Preliminary report on the rescue excavation at Szurdokpüspöki - Hosszú-dúlö II-III. (M21 site No. 6-7)

Kristóf FüLÖP - Gábor VÁcZI

Preliminary report on the excavation of a new Late Bronze Age cemetery

from fobbágyi (North Hungary)

Lőrinc TimÁr - Zoltán CzAJLik - András BöDőcs - Sándor PuszTA

Geophysical prospection on the Pâture du Couvent (Bibracte, France). The campaign of 2014

Dávid BARtus - László Borhy - Gabriella Delbó - Emese SzÁmadó

Short report on the excavations in the civil town of Brigetio (Szőny-Vásártér) in 2014

Dávid BARTus - László BorHy - Emese SzÁMADó

A new Roman bath in the canabae of Brigetio

Short report on the excavations at the site Szőny-Dunapart in 2014

Dávid BARTus - László Borhy - Zoltán CzAjlik - Balázs Holl -

Sándor PuszTA - László RuPNiK

Topographical research in the canabae of Brigetio in 2014

Zoltán CZAJLIK - Sándor BERECKI - László RUPNIK

Aerial Geoarchaeological Survey in the Valleys of the Mureș and Arieș Rivers (2009-2013)

Maxim MoRDovin

Short report on the excavations in 2014 of the Department of Hungarian Medieval

and Early Modern Archaeology (Eötvös Loránd University, Budapest)

Excavations at Castles Čabrad' and Drégely, and at the Pauline Friary at Sáska

\section{Thesis Abstracts}

Piroska Csengeri

Late groups of the Alföld Linear Pottery culture in north-eastern Hungary

New results of the research in Borsod-Abaúj-Zemplén County

Ádám Bíró

Weapons in the 10-11th century Carpathian Basin

Studies in weapon technology and methodology - rigid bow applications and southern import

swords in the archaeological material

Márta DARÓcZI-SzABó

Animal remains from the mid 12th-13th century (Árpád Period) village of Kána, Hungary

Károly BELÉNYESY

A 15th-16th century cannon foundry workshop in Buda

Craftsmen and technology of cannon moulding and the transformation of military technology

from the Renaissance to the Post Medieval Period 
István RINGER

Manorial and urban manufactories in the 17th century in Sárospatak

\section{BIBLIOGRAPHY}

László BORHY

565

Bibliography of the excavations in Brigetio (1992-2014) 


\title{
Aerial Geoarchaeological Survey in the Valleys of the Mureş and Arieş Rivers (2009-2013)
}

Zoltán CZAJLIK

SÁNDOR BERECKI

Institute of Archaeological Sciences

Eötvös Loránd University

czajlik.zoltan@btk.elte.hu

Mureş County Museum

sberecki@yahoo.com

\author{
LÁSZLó RUPNIK \\ MTA-ELTE Research Group \\ for Interdisciplinary Archaeology \\ rupnik.laci@gmail.com
}

\begin{abstract}
The paper presents the most important results of the Romanian-Hungarian aerial archaeological project, i.e. the intensive topographic research of the Middle Mureş Valley. Situated between the mountains, in the widening valley section various aged/high terraces were formed, providing proper conditions for human habitats. Beside the already documented stone buildings from the Roman period, observed due to the negative crop marks - especially in 2013 - positive crop marks of settlements datable before and after the Roman period were observed in large variety. The simultaneous examination of the geomorphological conditions underlined significant differences between the prehistoric and Roman strategies of settlement establishment.
\end{abstract}

\section{Introduction}

The results of the research, ${ }^{1}$ which started in 2009 based on a constant collaboration of three institutions - the Institute of Archaeological Sciences of the Eötvös Loránd University (Budapest), Mureş County Museum (Târgu Mureş) and Museum of Unification from Alba Iulia were published on several occasions. ${ }^{2}$ One of the main objectives of the program was the adaptation of the methods successfully applied earlier in Hungary, namely the transposition of the surveying technique elaborated for the monocultural agriculture of the mountainous, morphologically very diverse Transylvanian landscape, with varied cultivation endowments.

The employment of aerial surveys in the archaeological research of the region is not without antecedents: earlier, a British-Romanian project focused on the Mureş Valley, ${ }^{3}$ while the eastern limes of Dacia was mapped by another Hungarian-Romanian collaboration. ${ }^{4}$ Significant new results were also obtained in the research of the south-eastern Transylvanian territories. ${ }^{5}$

1 This work was supported by a grant of the Romanian Ministry of Education, CNCS-UEFISCDI, project number PN-IIRU-PD-2012-3-0316 and the research projects of the Hungarian Scientific Research Fund (OTKA 68 824/77325, 111 058).

2 Czajlik et Al. 2011; Berecki et AL. 2012; Berecki et Al. 2013.

3 Oltean - Hanson 2001; Hanson - Oltean 2003; Oltean 2007.

4 PÁnCZÉl ET AL. 2011.

5 Sófalvi 2013a; Sófalvi 2013b. 
Based on the earlier topographic data available for the Transylvanian Basin ${ }^{6}$ several known archaeological sites (mostly fortifications, barrows, Roman sites and medieval monuments) were documented during the flights. During navigation the list of coordinates and the GE overlays were simultaneously used for the recognition of sites.

\section{Technical background}

The airplane used for the aerial photography in our project is a CTSW type ultra light plane supplied by the Aero Consulting Co. from Deva every year, the pilot is Simion Câmpean. A Nikon D300 camera with a Nikkor ED 24/70 objective and a Canon EOS 7d camera with EF 24-105mm f/4L IS USM objective were used. The coordinates were recorded with a Garmin GPS, directly transferred into the RAW file. For the identification and mapping of the photos taken from the air, László Rupnik used the references of Google Earth combined with the Third Military Survey (1869-1887) and all the data were provisionally stored in a Google Earth layer and Excel files.

The first surveyed area was the Transylvanian Plain, which is rather unknown from the aspect of archaeological topography. Later, the researched region was highly expanded, this area extended in the Mureş Valley at Deva and the Southern Carpathians, towards Cluj at the confluence of the Someşul Cald and Someşul Rece rivers, to the north up to the GherlaDej-Reghin line, to the east in the Ciuc Basin and along the Olt River to the Bârsa Basin, and to the south in the valleys of the Târnave Rivers. In 2009 the survey was undertaken in the surroundings of Satu Mare, while in 2012 small reconnaissance flights took place in the Romanian Banat. In the Mureş valley two base airports were used: Târgu Mureş and Deva. Thus, a $400 \times 300 \mathrm{~km}$ area could be covered (Fig. 1).

Based on the more than 90 hours of flights performed between 2009 and 2013 (Zoltán Czajlik 86; Sándor Berecki 7) it can be concluded that the possibilities of identifying crop marks are the best on the middle course of the Mureş River, explainable partially by the relatively large plot agriculture. It should be noted that in the Transylvanian Plain - at Fântânele (BistriţaNăsăud County, Hung. Szászújős) for example - and in south-eastern Transylvania, in the valley of the Olt River, crop marks were observed in pastures and meadows as well.

The early summer flights - relevant in the case of crop mark identification - were made on different dates: between 26th and 28th June in 2009; between 8th and 10th June in 2010; on 22nd and 23rd June in 2011, between 17th and 19th June in 2012 and between 2nd and 4th July in 2013. Besides the early summer period, further flights took place in the early spring (23rd March 2012) and autumn (6th-7th October 2012, 13th-14th November 2013). Hitherto, the best circumstances were observed in July 2013, during the flight, just prior to the harvest time, in terms of the number of identified archaeological sites and their extent as well as the possibilities of their interpretation.

It should be underlined that the Transylvanian crop marks are burdened by numerous prob-

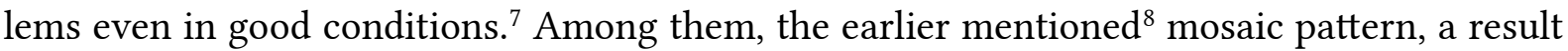

\footnotetext{
6 In the data collection several colleagues from the Transylvanian institution were involved (Gabriel Rustoiu from the Museum of Unification, Alba Iulia; Mariana Egri from the Babeş-Bolyai University, Cluj-Napoca; Aurel Rustoiu from the Institute of Archaeology and Art History, Cluj-Napoca; Iosif Vasile Ferencz from the Museum of Dacian and Roman Civilisation, Deva and Sándor József Sztáncsuj from the National Szekler Museum, Sfântu Gheorghe), whom hereby we would like to thank.

7 Oltean 2007, 20-21.

8 CZajlik et Al. 2011, 12.
} 
of the narrow plot agriculture is well known, as well as the non-archaeological growth and colour disparities caused by the uneven fertilizing. It is less known, however, that even though the Mureş River Valley is one of the most appropriate areas in terms of aerial photography, the effect of the geological background and the disturbance inflicted by the altering alluviums of the Mureş River causes many difficulties.

\section{Geomorphology of the middle course of the Mureş River}

It is a well known archaeological topos that the Mureş Valley is one of the most important natural communication routes leading to the inland of the fully enclosed Transylvanian Plateau. The settlements of the various prehistoric cultures took advantage of both the potential provided by the 'commercial routes' of the valley and the richness in raw materials and minerals of the surrounding mountains. At the end of the Late Iron Age and in the Roman period the importance of the middle valley section seems to increase, which most probably can be connected to the appreciation of the role of the roads leading through the Southern Carpathians. ${ }^{9}$

The advantage of the conventional aerial archaeological research, unlike all other modern methods, is given by the possibility of the researcher to accommodate in the physical sense with the landscape, as he/she is able to fly over the valleys and can search for and locate the plateaus appropriate for settlement establishment or peaks suitable for fortifications, etc. Therefore, the research requires not only archaeological but also geographical, geomorphological and hydrographical knowledge; at the same time it is able to bring new results for both archaeology and the mentioned auxiliary disciplines. ${ }^{10}$

Geomorphological particularity observed during the aerial topographical research is the permanence of certain sections of the riverbed in historical times (several onetime settlements can be found today immediately on the riverside) while in other cases - especially at the confluence of the main tributaries like the Arieş and the Sebeş rivers - remarkable changes of the riverbed and traces of alluvial fans emerged. However, smaller meander divagations can be observed on the entire researched section and - as mentioned in the introduction - by giving an inhomogeneous background this phenomenon makes the aerial archaeological observations difficult. Nonetheless, archaeological sites were identified some times "above" the silted riverbed wreckages (Fig. 2); furthermore it cannot be excluded that beneath/amid the silts there could be entirely concealed sites. The fact that in the Mureş Valley there are several settlements with both Neolithic and Iron Age traces - for example Turdaş (Hunedoara County, Hung. Tordos $)^{11}$ - confirms the hypothesis concerning the relative stability of the Mureş River. According to the present experiences this would mean that in the historical times probably no major meander migrations should be taken into account, the river had its present course, which does not exclude frequent changes of the tributaries' bends and the estuaries.

This should be connected to the - already mentioned ${ }^{12}$ - capability of the Mureş River to transport and deposit sediments, which caused geomorphologic changes influencing the choices of the specific sites for habitation in historical times. During the earlier surveys significant differences between the positive and negative crop marks have been observed in

9 cf. also Oltean 2007, 30.

10 For general geographical background see: ANDó 1995, especially 1-15, figure 4.

11 LuCA 2012.

12 BERECKI ET AL. 2013, 88. 
favour of the latter, explained with the alluvial sediments meaning the preponderance of clays against the sandy soils. ${ }^{13}$ We have not made similar observations; however it is obvious that while the prehistoric sites (and settlements from other periods characterized by sunken featured buildings) are visible due to positive crop marks, the stone architecture of the Roman period can be traced by negative crop marks. Because the field confirmation of the age of the sites is a next step of the project, the two types of crop marks are going to be discussed separately.

\section{Examples for positive crop marks}

The fortified settlement from Uroi-Măgura Uroiului (Hunedoara County, Hung. Arany) has been documented in several cases. The fortification of the northern part of the prehistoric site sectioned during the archaeological campaigns from 2006 and dated to the Early and Late Iron Age $^{14}$ - was sighted during the aerial surveys in June 2009, when the ditch of the fortification was marked by the vegetation. ${ }^{15}$ During the documentation in 2013 on the southern terrace of the hill, on the pasture overlooking the Mureş River traces of pits were observed (Fig. 3).

In the outskirts of the village Folt (Hunedoara County, Hung. Folt) several archaeological sites are known. On the right bank of the Mureş River, on the second terrace, close to the road leading to Geoagiu, Middle Bronze Age (Wietenberg culture), Early Iron Age, Roman and Migration period finds are known, while $150 \mathrm{~m}$ south of this site further Roman discoveries are mentioned. North of the village where the creek crosses the road leading to Geoagiu, traces of a Roman settlement were documented. ${ }^{16}$ In 2013 pits indicating the existence of a settlement were observed by following the edge of the northern terrace. The steep edge of the terrace is clearly visible on the photograph, which in spite of the small farming plot allowed the observation of settlement traces (Fig. 4).

At Şibot (Alba County, Hung. Alkenyér), on the left bank of the river, in the wide terrace-island lying in the middle of the Mureş valley, the identification of an extended settlement was possible due to the tracking of the alluvial terrace-margins. The site could be the same with the one identified through field walking and still not researched - a settlement with findings from the Copper Age (Coţofeni culture) and Early Medieval period. ${ }^{17}$ Probably because of the thick alluvial stratum specific to the Mureş Valley the archaeological features are only visible on the alluvial terrace-margin, exposed to erosion (Fig. 5).

The archaeological features were observed in the same conditions near Aiud (Alba County, Hung. Nagyenyed), at the place called Cetăţuie, Cetatea Tinoasă, Sárvár or Sárvárdomb, known from the 19th century (Fig. 6). The impressive plateau is situated on the first terrace of the Mureş River, $3 \mathrm{~km}$ south-east of the city, between the present riverbed and the backwater of the river. Here, traces of settlements from several periods were recorded; however the researches were limited to a small scale rescue excavation. ${ }^{18}$ On the photographs, at the highly eroded edge caused by the land cultivation, positive crop marks indicating archaeological features were observed. The findings revealed due to the disturbances caused by the

13 Oltean 2007, 20-21.

14 Pescaru 2007, 287.

15 Berecki et AL. 2013, Plate V/1.

16 LuCA 2005, 69-70, nr. 173; LuCA 2008, 75-76, nr. 173; with further bibliography.

17 Moga - Ciugudean 1995, 180-181, nr. 179/2.

18 Moga - Ciugudean 1995, 20-21, nr. 3/3. 
gravel quarry in the 1970s were dated to the Neolithic, Copper Age (Cotgofeni culture), Middle Bronze Age (Wietenberg culture), Early Iron Age (Basarabi culture), Roman and Migration period.

At Lancrăm (Alba County, Hung. Lámkerék) the traces of newly recorded settlements observed at the external curve of the silted meanders of the Sebeş River, tributary of the Mureş River, should be linked to the riverbed, still active in those times. The captures show not only the interfering effect of the geological background, but also warn about the possibility of meander relocations in historical times (Fig. 7).

At Beldiu (Alba County, Hung. Marosbéld) a low terrace formed by the meanders ensured the conditions of establishing the settlement indicated by the sunken featured buildings of a previously unknown site (Fig. 8). The same situation was observed at Mihai Viteazu (Cluj County, Hung. Szentmihály), where 8-10 similar buildings were detected on the territory of a newly identified site (Fig. 9).

The site recorded at Luncani in 2009 (Cluj County, Hung. Aranyosgerend), which later proved to date from the Early Migration Period, ${ }^{19}$ already draws the attention upon the possibility of identifying the complex settlements structure in the valley of the Arieş River. The northernmost example known in the present is the eastern periphery of the industrial zone of Turda (Cluj County, Hung. Torda), where traces of sunken features were recorded (Fig. 10). This is the area where the Roman cemetery of Potaissa is known $2.7 \mathrm{~km}$ south of the military camp, along the Turda-Mihai Viteazu road, where several sarcophagi and brick graves were unearthed. ${ }^{20}$

\section{Examples for negative crop marks: Roman settlement features}

The military camp of Micia and the surrounding settlement (Fig. 11) are situated on the shores of the Mureş River at Veţel (Hunedoara County, Hung. Vecel). According to the earlier and present archaeological excavations several construction phases have been identified. The site was intensively researched by aerial archaeological methods as well, and a significant part has already been mapped. ${ }^{21}$ Due to the modern farming the negative marks of the roman buildings occur only in smaller parcels, therefore the plan can be periodically updated and broadened with newer details (Fig. 12). During the aerial surveys performed in 2013 a few features were documented in the south-eastern side of the camp; among them a building was firstly identified with several compartments, apparently paved floor and a semicircular apse. In addition, a section of the northern rampart of the camp with the traces of at least two semicircular side towers could be observed. The situation is similar in the case of the auxiliary camp and settlement of Germisara (Hunedoara County, Cigmău, Hung. Csigmó, administratively Geoagiu, Hung. Algyógy), which is also built on the higher terrace of the river. The site itself is well known and mapped data are also available. ${ }^{22}$ The military camp situated on the high terrace of the right riverbank at Războieni-Cetate (Alba County, Hung. Székelyföldvár) belongs to the same category of Roman castra found elsewhere in the Mureş Valley. Similarly to the examples of Micia and Germisara, due to the previous aerial archaeological survey a significant part of the plan has already been discovered. ${ }^{23}$

19 CZAJLIK ET AL. 2011, plate 3.

20 CRIŞAN ET AL. 1992, 402, nr. Turda/48.

21 OlteAn 2007, 156-158, figure 5.28.

22 Oltean 2007, 158, figure 5.29; Berecki et AL. 2013, 95, plate IX.

23 Oltean 2007, 158, figure 5.30; BERECKI ET AL. 2013, 95, plate VIII. 
Besides the Roman military settlements known from the 19th century, particular interest was given to civilian settlements. In the vicinity of Geoagiu, on a higher terrace, traces of a previously unknown building complex were documented (Fig. 13). The dwellings were lying approximately $800 \mathrm{~m}$ north of the Roman road (also visible on Google Earth) heading northeast from the vicus of Germisara. According to the narrow plot system the plan of the feature can only be partially defined; nevertheless it can be assumed that a Roman villa might have been documented. Regarding its position it can be mentioned that the building complex was established at the entrance of the valley connecting the Mureş Valley with the Roman baths and cult centre of Geoagiu-Băi (Hunedoara County, Hung. Feredőgyógy).

South of Sibişeni (Alba County, Hung. Sibisány), in the proximate vicinity of the motorway, positive anomalies of pits and other archaeological features, together with negative crop marks of walls belonging to buildings of a Roman villa emerged (Fig. 14). Traces of a Roman settlement have already been mentioned in this area; ${ }^{24}$ furthermore, rescue excavations preceding the construction of the motorway were carried out in the surrounding area. Similarly to the case of Geoagiu, the settlement was placed at the entrance of a small watercourse, protected from the inundations of the Mureş.

In the vicinity of Oarda (Alba County, Hung. Alsóváradja) traces of buildings with a more simple structure, compared to the previously mentioned ones emerged. ${ }^{25}$ The geographical position is similar: a higher terrace at the confluence of two watercourses. However, its dating would be accurately defined by means of field surveys; according to its ground plan we assumed that this building complex belongs to the Roman period. Some buildings have been clearly overlaid by other stone structures, therefore the place must have been inhabited in at least two periods. The presumption is supported by the fact that numerous Roman finds are known from the territory and surroundings of the village (Fig. 15). ${ }^{26}$

The already known and the newly identified sites or site-details presented above were recorded without exception on the middle course of the Mureş River, between Deva and the estuary of the Arieş River, as well as in the valley of the Arieş River up to the surroundings of Turda. Besides this region - as in the earlier years - no crop marks could be observed in 2013, and since the vegetation background did not change radically, this could be argued by the variation of the geomorphologic background.

The region covered by the present survey corresponds to the one defined by geomorphologists as the Mureş-Arieş River Corridor. This corridor includes the section of the valley of the Mureş River between the Arieş River and the estuary of the Strei River, ${ }^{27}$ to which - in concordance with the aerial topographical observations - the section of the valley of the Aries River up to Mihai Viteazu was attached. ${ }^{28}$ Regarding the western border, the aerial archaeological observations extend it with at least $10 \mathrm{~km}$ westwards, while the geomorphological border can only be "flexibly" defined. ${ }^{29}$ As it is underlined by the geomorphological analysis, the particular character of the Mureş-Arieş River Corridor is emphasized by two factors: firstly, it is the only section of the Mureş River in Transylvania which, based on the steep gradient

24 Moga - Ciugudean 1995, 209, nr. 213/10.

25 The site was already published, see: Oltean 2007, 126-130, Figure 5.8-9.

26 Moga - Ciugudean 1995, 132, nr. 125/1-2; Figure 11.

27 PANDi - HoRvÁTH 2012.

28 Costea 2009, 7, Figure 1.

29 PANDI ET AL. 2013, 97-98. 
and water velocity, has a lower course character; secondly, this low gradient section has a large area at the valley bottom. ${ }^{30}$ Thus, this long, wide and low gradient valley bottom from the middle course - locally - offered similar conditions for the foundation of habitats and agricultural activity which remind of the westernmost section of the Mureş River from the edge of the Great Hungarian Plain (Fig. 16).

Ioana Oltean ${ }^{31}$ observed that the plains occupy a relatively limited area, all of them have alluvial origins and they developed along the Mureş and its main tributaries. Some of the terraces date from the Pleistocene, but the lower ones are from the old Holocene. ${ }^{32}$ Therefore, during the research of the Mureş Valley special attention was given to the study of the plateaus and terraces appropriate for human habitation (Fig. 17). Without intending to present the detailed relationships of the morphologically and geologically different terrace levels and habitation periods, it should be mentioned that - referring back to the cited observations of Oltean ${ }^{33}$ - the existing experiences indicate that the non-Roman settlements characterised by positive crop marks can be found from the small hills to the lower terraces in every geomorphological situations, while the Roman sites, traced due negative crop marks of stone structures were observed until now - except a part of Germisara - mostly on the higher terraces of the Mureş and Arieş Rivers.

The military occupation of the Mureş-Arieş River Corridor in Roman times was necessary in order to the control the roads leading into the Transylvanian Basin as well as the raw materials (iron, gold, silver, copper, salt, etc.) of the surrounding mountains. The appearance of the military camps on flood-free terraces situated in the vicinity of water courses and of the settlement in the same areas shows the changes, the uniformisation of the earlier diverse strategy of settlement establishment. Their connection to the alluvial filling process of the downstream type areas observed also by aerial archaeological methods necessitates detailed field investigations. The modern GPS-based field walking, the geophysical prospection of certain areas and the detailed geomorphological surveys are indispensable for the further topographical research of this interesting valley section.

\section{References}

Andó, M. 1995: The geography of the River Maros (Mureş) and its river system. In: Hamar, J. SÁRKÁNY-Kiss, A. (eds.): The Maros/Mureş River Valley. A study of the geography, hydrobiology and ecology of the river and its environment. Tisica Monograph Series. Szolnok - Szeged Târgu Mureş, 7-23.

Berecki, S. - Czajlik, Z. - Soós, Z. (eds.) 2012: Historical landscapes. Aerial Photographs of Transylvanian Archaeological Sites and Monuments / Történelmi látképek. Erdélyi régészeti lelóhelyek és múemlékek légi felvételei / Panorame istorice. Situri arheologice şi monumente istorice din Transilvania în fotografii aeriene. Catalogi Musei Marisiensis, Seria Archaeologica I. Budapest Târgu Mureş.

Berecki, S. - Czajlik, Z. - Rupnik, L. 2013: Aerial Archaeological Prospection on the Middle Course of the Mureş River and Adjacent Areas. Apulum 50, 87-109.

30 PANDi et AL. 2013, 99, table 1.

31 Oltean 2007, 29.

32 Andó 1995, 13, figure 4.

33 Oltean 2007, 20-21. 
Costea, M. 2009: Morpho-hydrographical and modeling features of the Arieş river basin (Transylvania, Romania). Transylvanian Review of Systematical and Ecological Research 7, 1-10.

Crişan, I. H. - Bărbulescu, M. - Chirilă, E. - Vasiliev, V. - Winkler, I. 1992: Repertoriul arheologic al judeţului Cluj. Bibliotheca Musei Napocensis 5. Cluj-Napoca.

Czajlik, Z. - Berecki, S. - Rupnik, L. - Sztáncsuj, S. J. 2011: Preliminary Report on the Aerial Archaeological survey in Transylvania (2009-2010). Marisia 31, 7-17.

Hanson, W. S. - Oltean, I. A. 2003: The identification of Roman buildings from the air: recent discoveries in Western Transylvania. Archaeological Prospection 10, 101-117.

LucA, S. A. 2005: Repertoriul arheologic al județului Hunedoara, Bibliotheca Septemcastrensis 14. Sibiu.

LucA, S. A. 2008: Repertoriul arheologic al județului Hunedoara, ediţia a doua, Bibliotheca Septemcastrensis 16. Sibiu.

LucA, S. A. (ed.) 2012: Cercetările arheologice preventive de la Turdaş - Luncă (jud. Hunedoara). Campania 2011. Sibiu.

Moga, V. - Ciugudean, H. (eds.) 1995: Repertoriul arheologic al județului Alba, Bibliotheca Musei Apulensis 2. Cluj-Napoca.

Oltean, I. A. 2007: Dacia. Landscape, colonisation and romanisation. London - New York - Routledge.

Oltean, I. A. - Hanson, W. S. 2001: Military vici in Roman Dacia: an aerial perspective. Acta Musei Napocensis 38/1, 123-134.

PAndi, G. - Horváth, Cs. 2012: Mureş River Middle Course Riverbed Dynamics between the Arieş and Strei Confluences. Aerul şi apa - Componente ale mediului, 49-56.

PÁnczéL, Sz. P. - SzABó, M. - VIsy, Zs. 2011: Dacia Superior keleti határának régészeti kutatása / Archaeological research on the Eastern frontier of Dacia Superior. In: Visy, Zs. - SzABó, M. Priskin, A. - LóKI, R. (eds): A Danube Limes program régészeti kutatásai 2008-2011 között / The Danube Limes project archaeological research between 2008-2011. Pécs, 173-180.

Pescaru, A. 2007: Rapoltu Mare, com. Rapoltu Mare, jud. Hunedoara. Cronica Cercetărilor Arheologice, campania 2006, 286-287.

PAndi, G., - Horváth, Cs. - Irimus, I. 2013: Mureş river hydro-morphological clustering. Aerul şi apa. Componente ale mediului - Air and water. Components of the Environment, Conferinţa 2223 martie 2013. Cluj, 95-102.

Sófalvi, A. 2013a: The border- and self-defence of Szeklers from the Medieval Age till the Age of Principality. Castles and other defence objects in the settlement history of Udvarhelyszék. Dissertationes Archaeologicae Ser. 3. No. 1, 339-366.

Sófalvi, A. 2013b: Ramparts in the Görgényi, Hargita and Persányi Mountains, In: CzAJlik, Z. BöDőcs, A. (eds.): Aerial Archaeology and Remote Sensing from the Baltic to the Adriatic. Selected Papers of the Annual Conference of the Aerial Archaeology Research Group, $13^{\text {th }}-15^{\text {th }}$ September, 2012, Budapest, Hungary. Budapest, 89-93, Plate 16. 


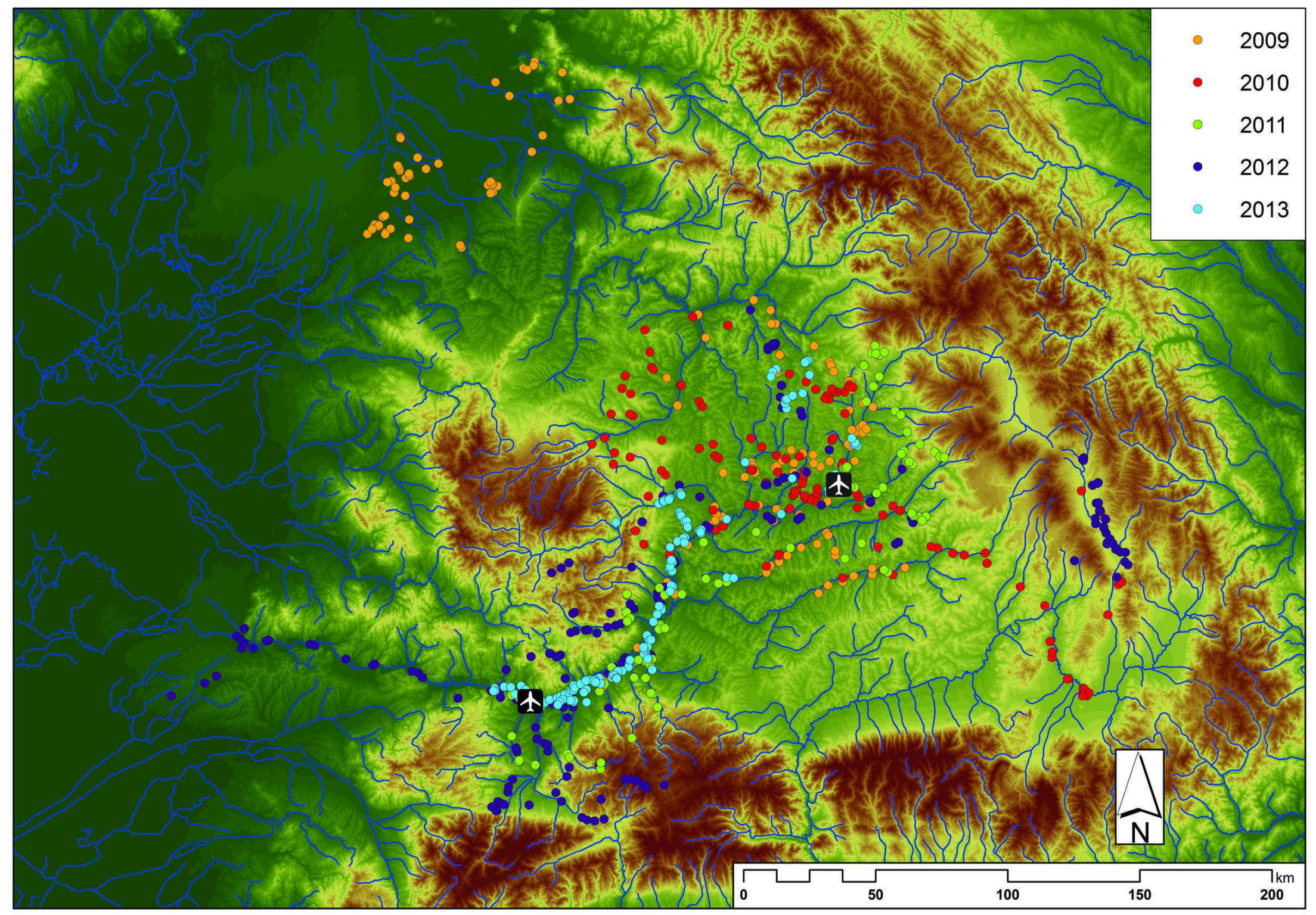

Fig. 1. The investigated area with the sites documented between 2009 and 2013 (L. Rupnik, May 2014). 


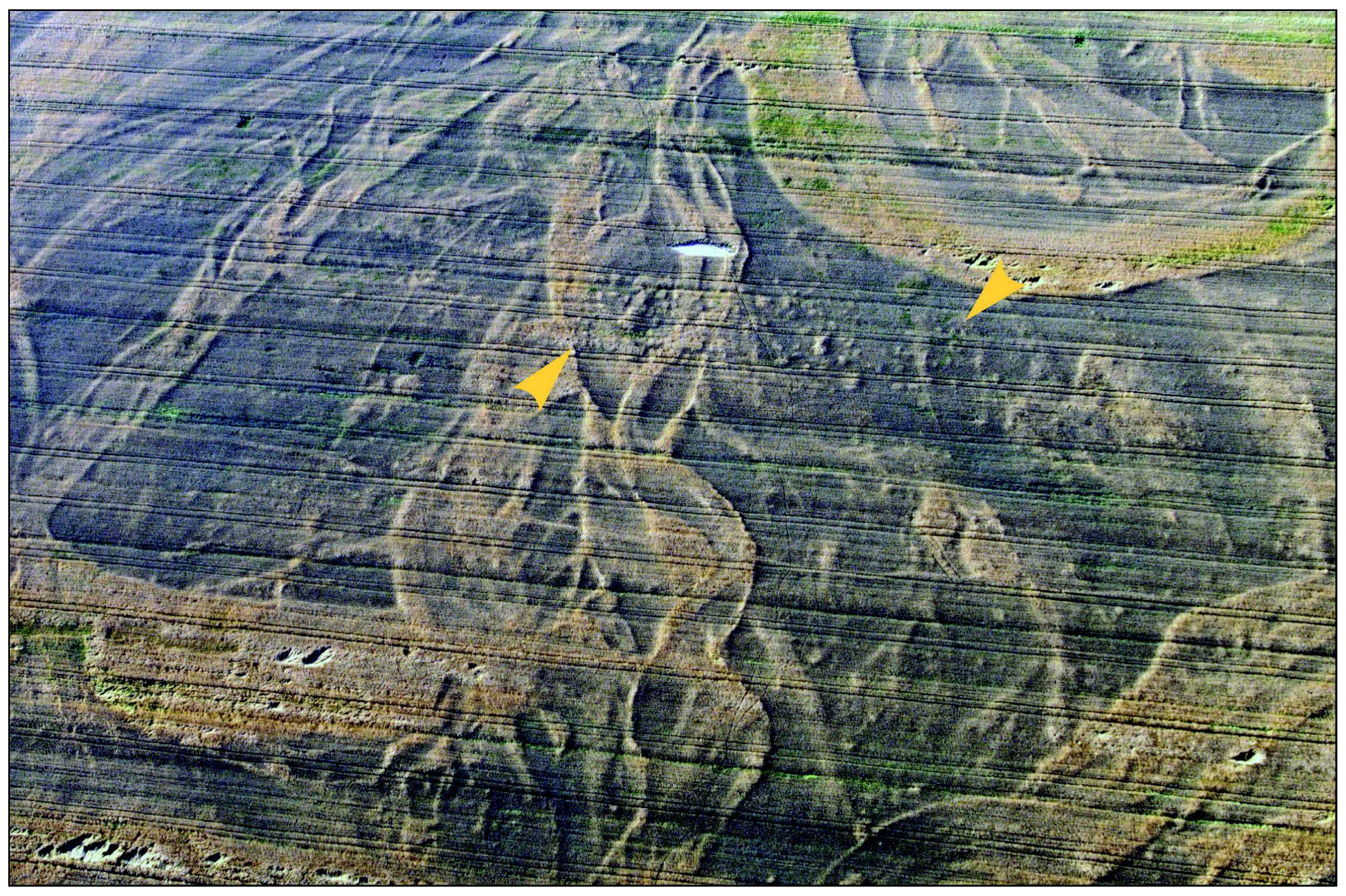

Fig. 2. The alluvial fan of the Sebeş River at Sebeş with traces of archaeological features younger than the riverbed marks (Photo: Z. Czajlik, 23rd June 2011). 


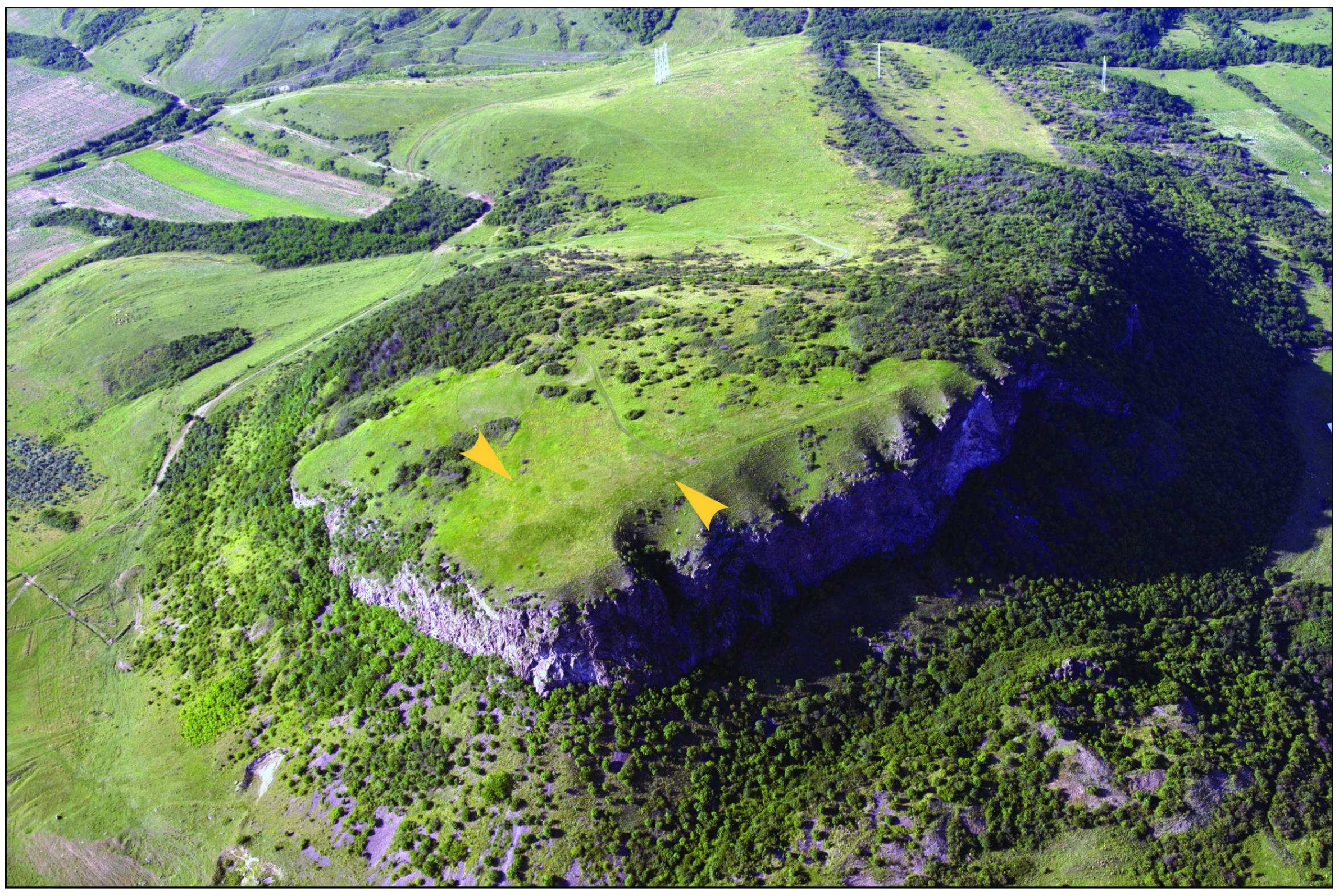

Fig. 3. Positive crop marks on terraces. Traces of pits at the fortified settlement from Uroi-Măgura Uroiului (Photo: Z. Czajlik, 2nd July 2013) 


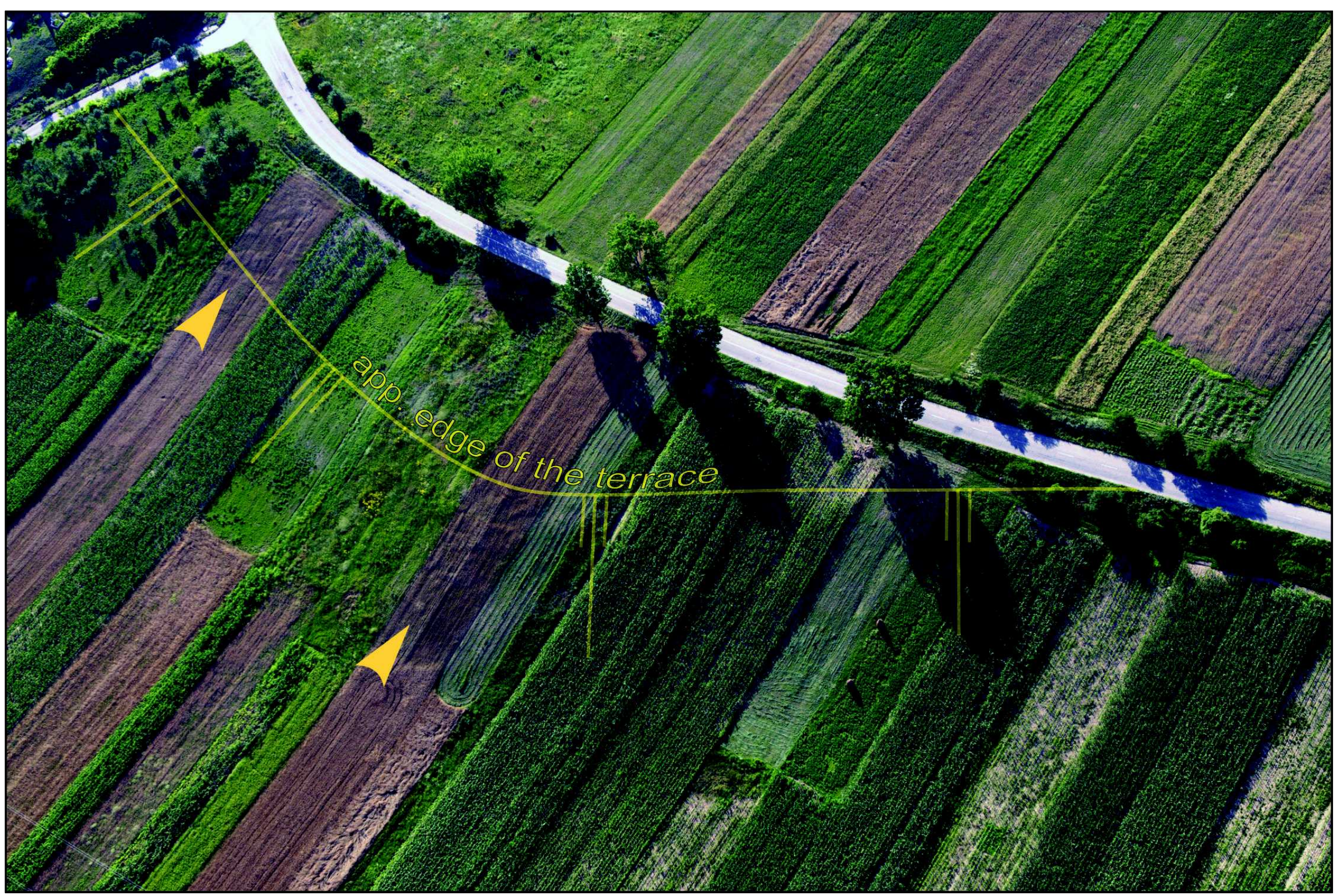

Fig. 4. Positive crop marks on terraces. Settlement traces at Folt (Photo: Z. Czajlik, 2nd July 2013; interpretation (using GE-imagery): L. Rupnik, May 2014). 


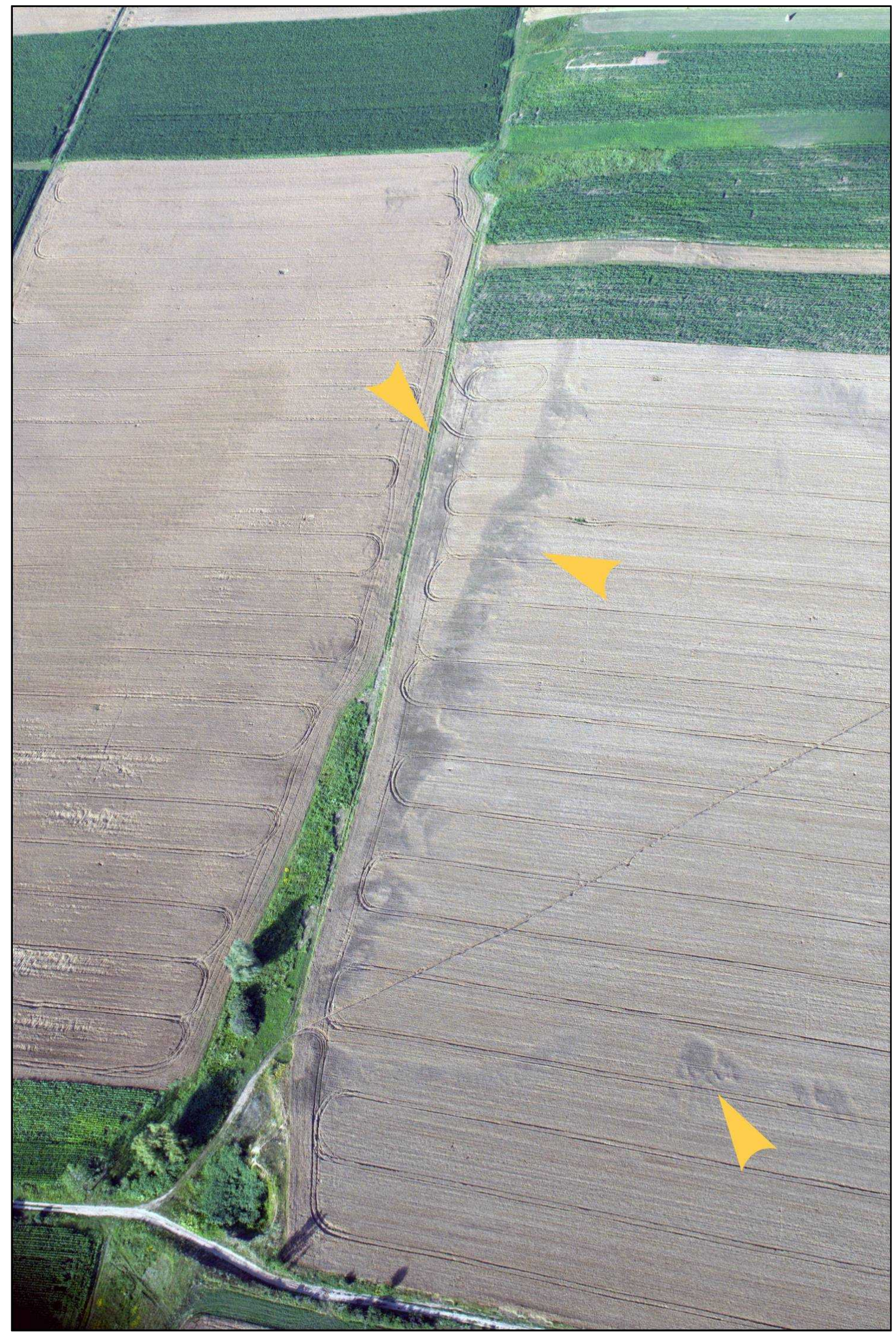

Fig. 5. Positive crop marks on terraces. Settlement traces at Şibot.

(Photo: Z. Czajlik, 2nd July 2013; interpretation (using GE-imagery): L. Rupnik, May 2014). 

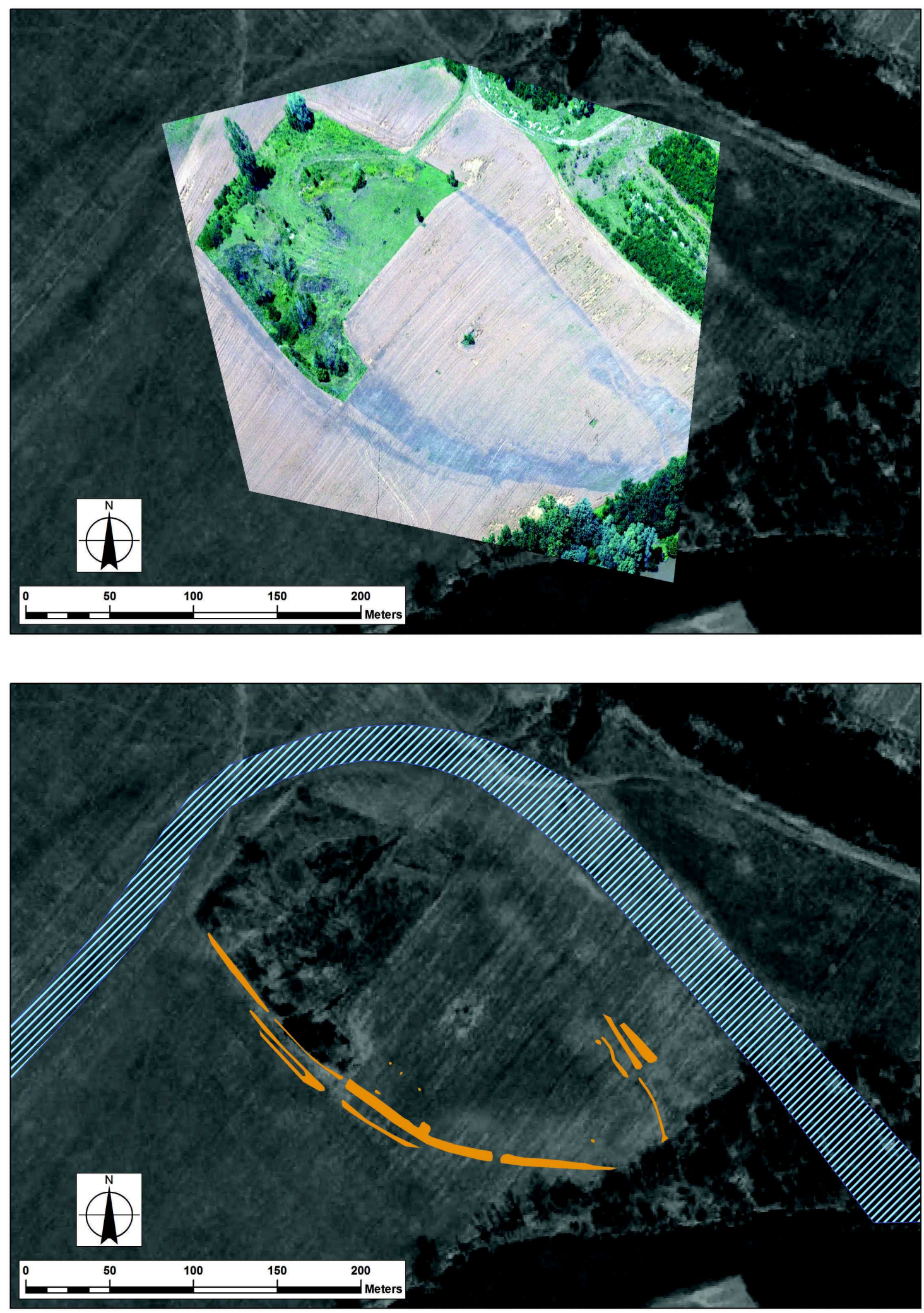

Fig. 6. Positive crop marks of the fortification ditch at Aiud.

(Photo: Z. Czajlik, 3rd July 2013; interpretation (using GE-imagery): L. Rupnik, May 2014). 


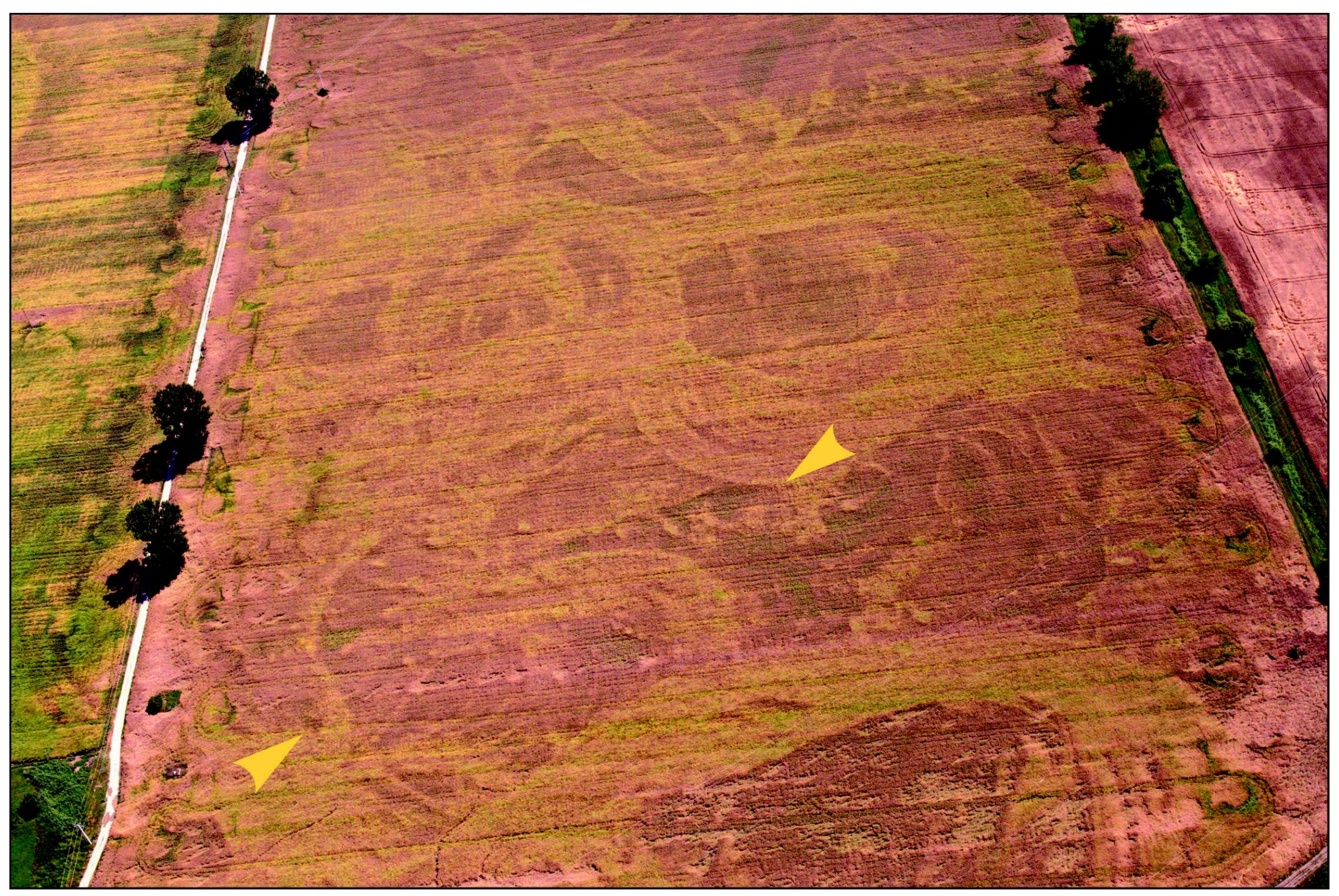

Fig. 7. Positive crop marks at the meanders. Settlement traces at Lancrăm (Photo: Z. Czajlik, 3rd July 2013). 


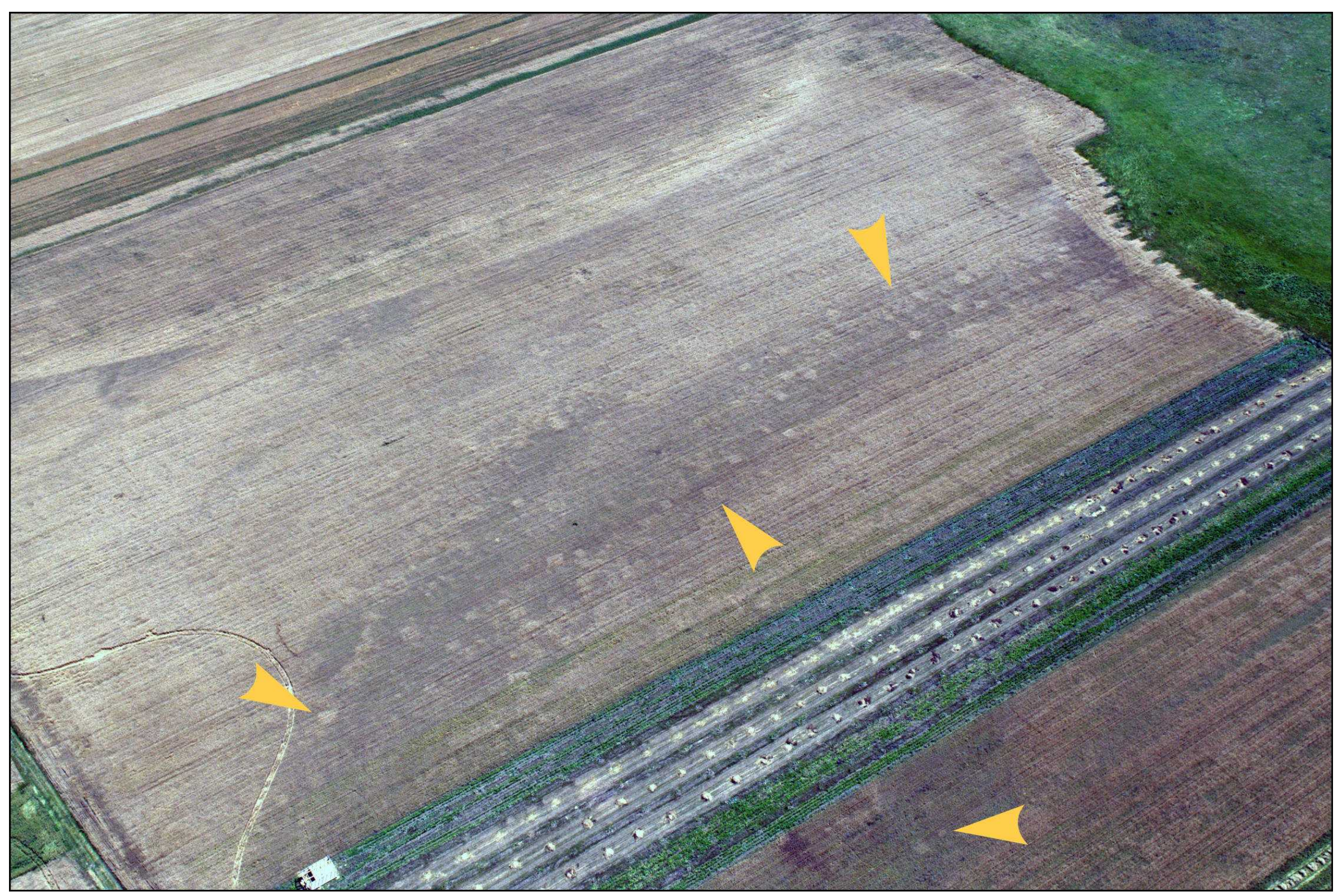

Fig. 8. Positive crop marks at the meanders. Settlement traces at Beldiu (Photo: Z. Czajlik, 3rd July 2013). 

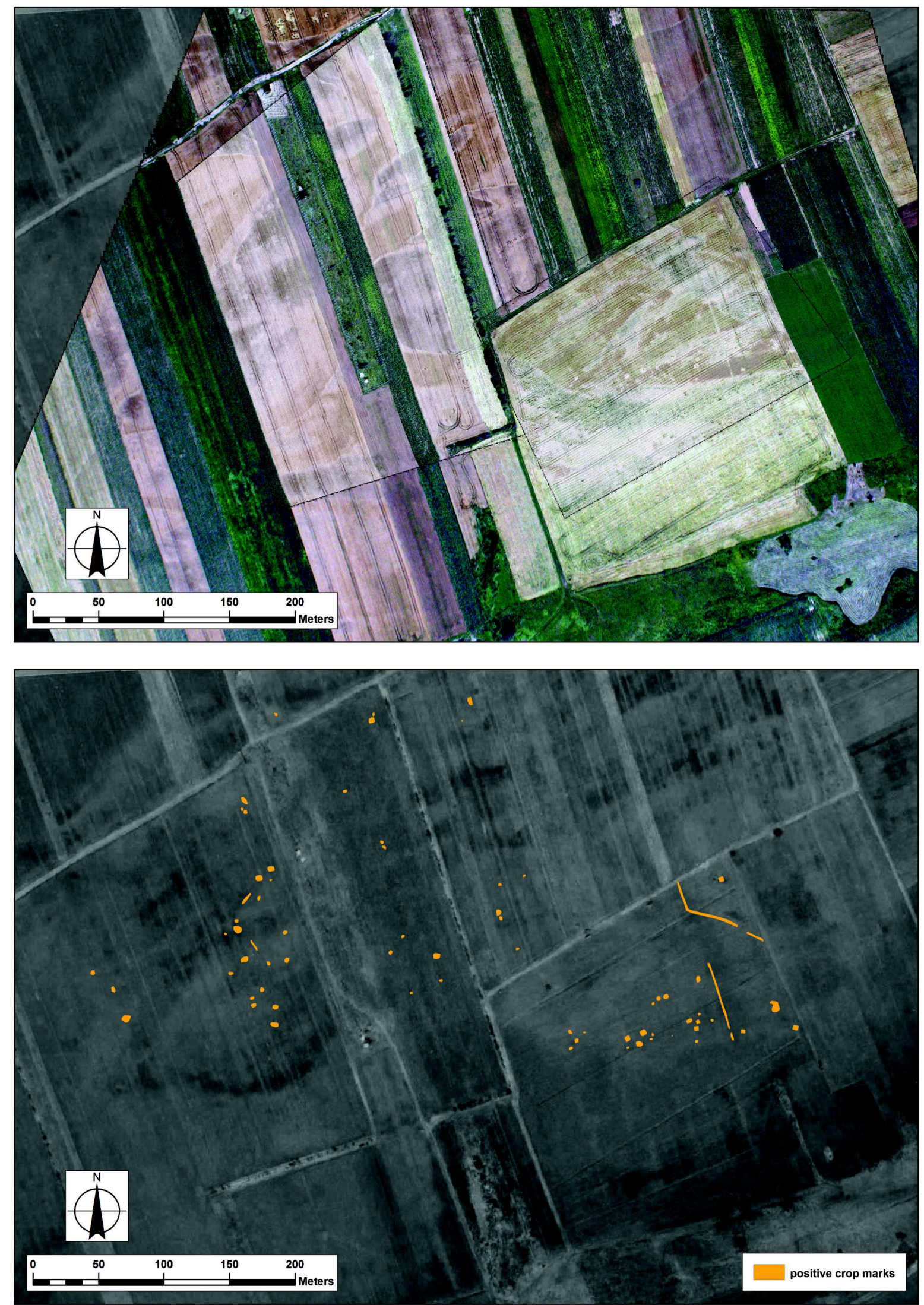

Fig. 9. Traces of an extended settlement consisting of semi-sunken dwellings in a land before harvest at Mihai Viteazu (Vizentúl) (Photo: Z. Czajlik, 3rd July 2013; interpretation (using GE-imagery): L. Rupnik, May 2014). 

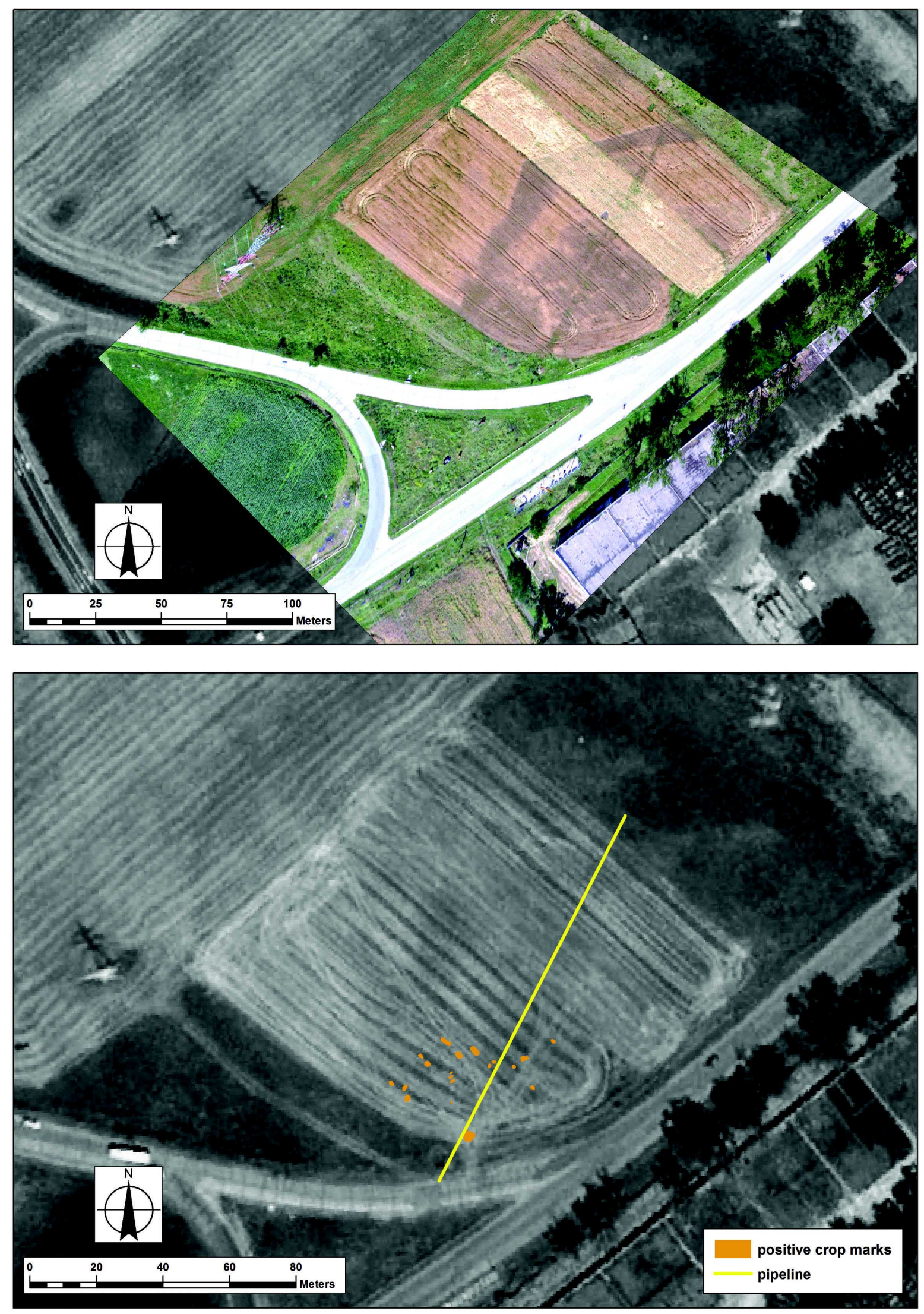

Fig. 10. Crop marks of settlement or cemetery features at Turda.

(Photo: Z. Czajlik, 3rd July 2013; interpretation (using GE-imagery): L. Rupnik, May 2014). 

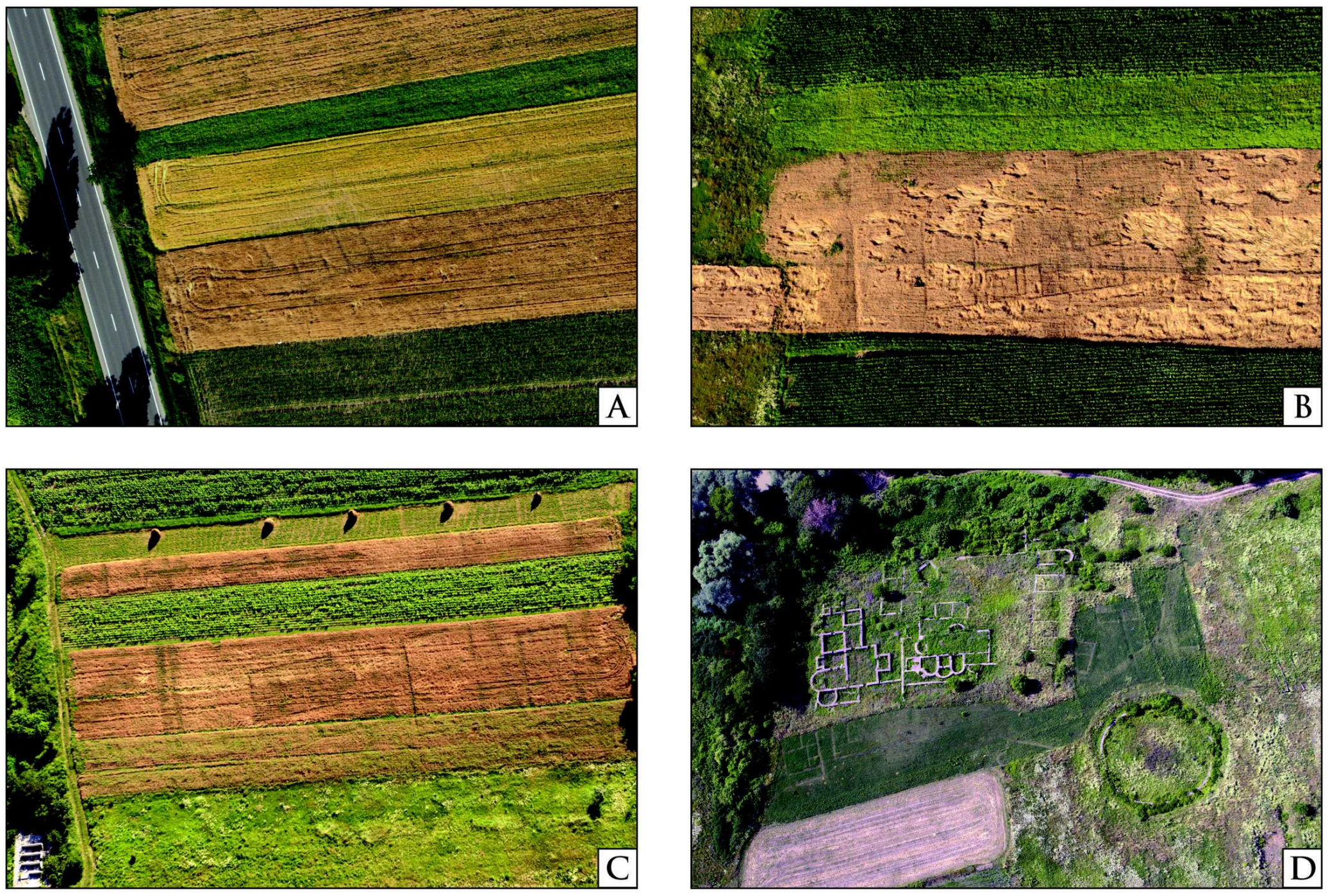

Fig. 11. The Roman military camp and the settlement of Micia (Veţel) (Photo: Z. Czajlik, 2nd July 2013; interpretation L. Rupnik, May 2014). 


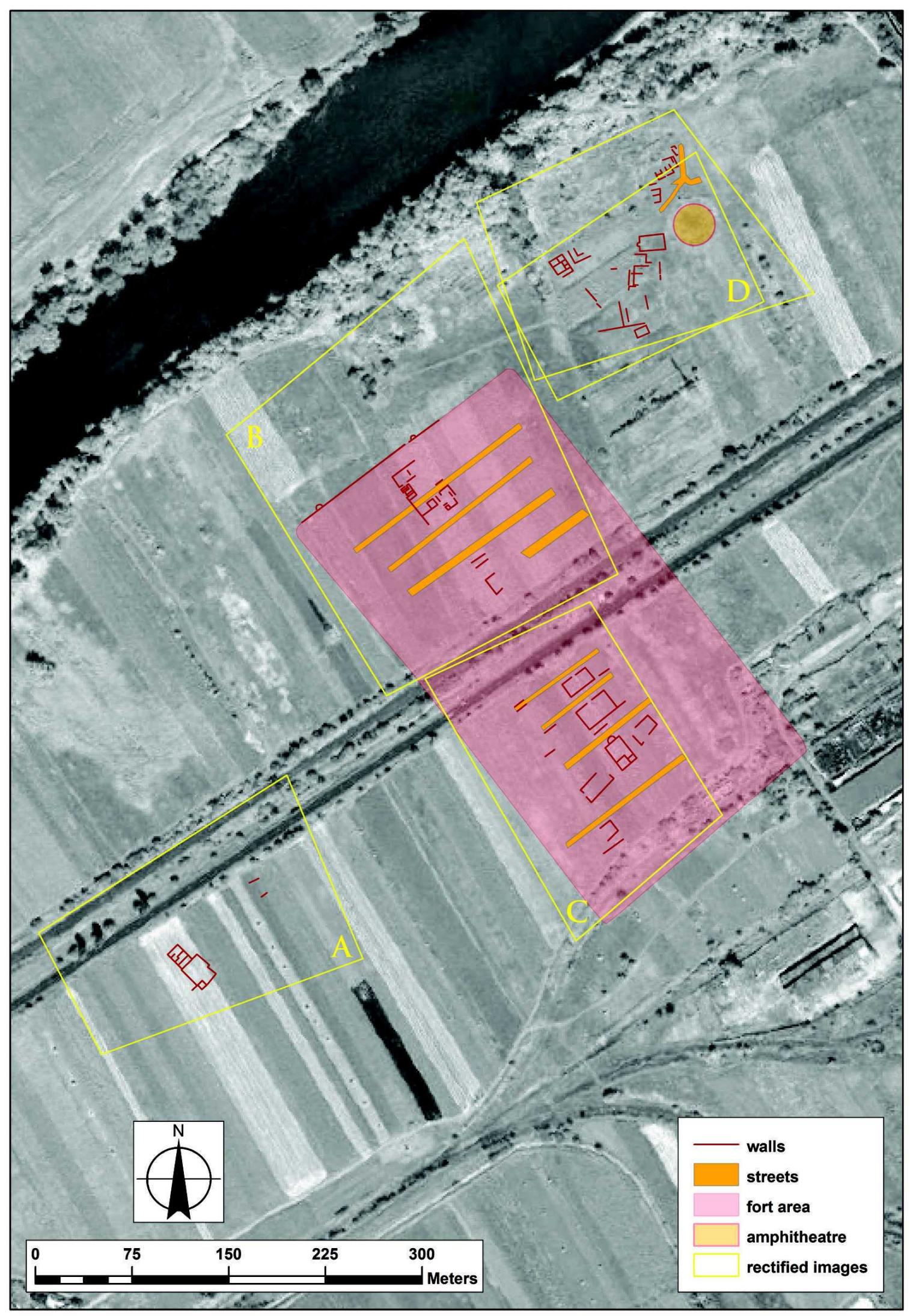

Fig. 12. The Roman military camp and the settlement of Micia (Veţel) (Photo: Z. Czajlik, 2nd July 2013; interpretation L. Rupnik, May 2014). 

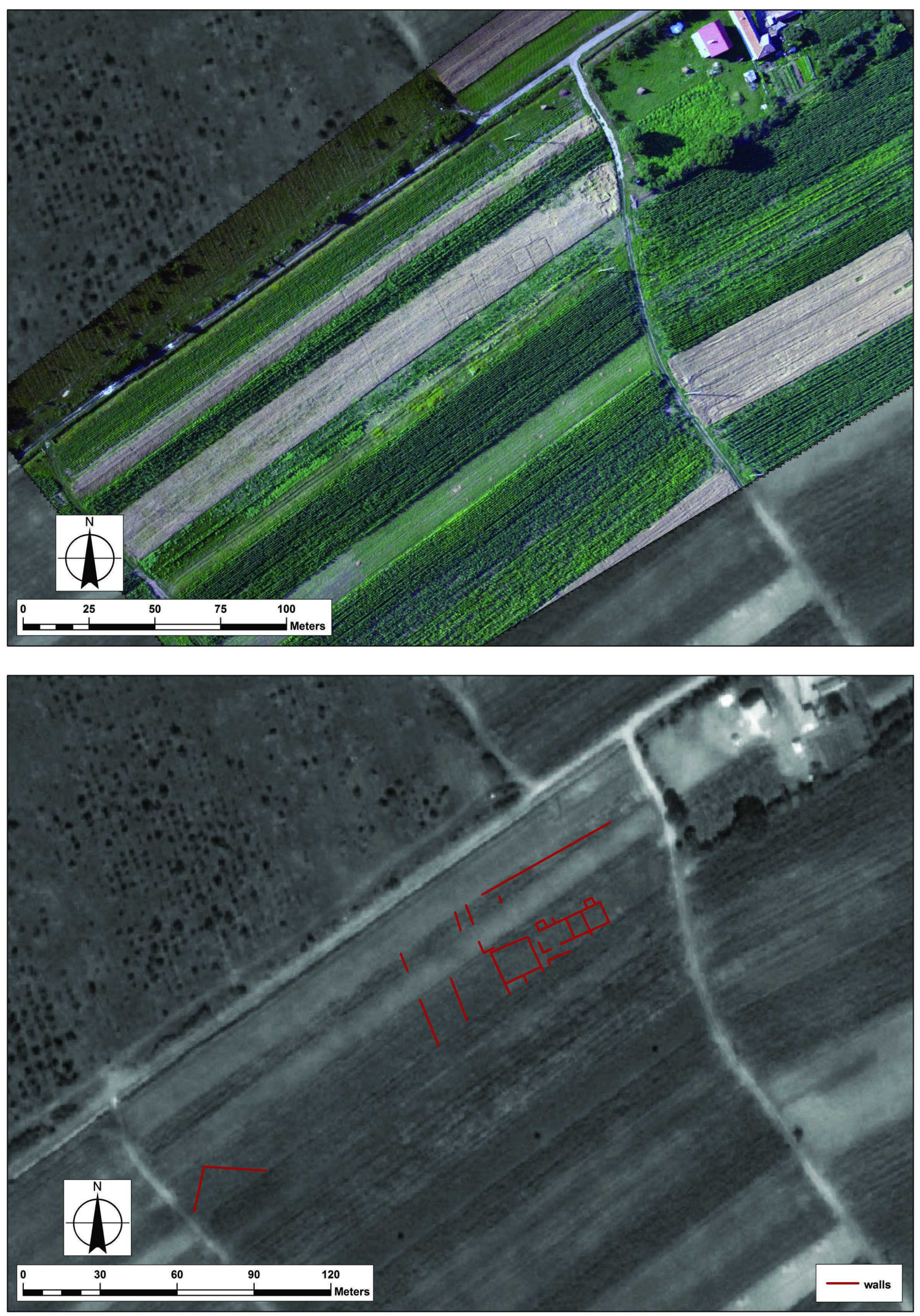

Fig. 13. Traces of the Roman road and settlement features at Geoagiu in lands with differently cropped cereals (Photo: Z. Czajlik 2nd July 2013; interpretation (using GE-imagery): L. Rupnik, May 2014). 

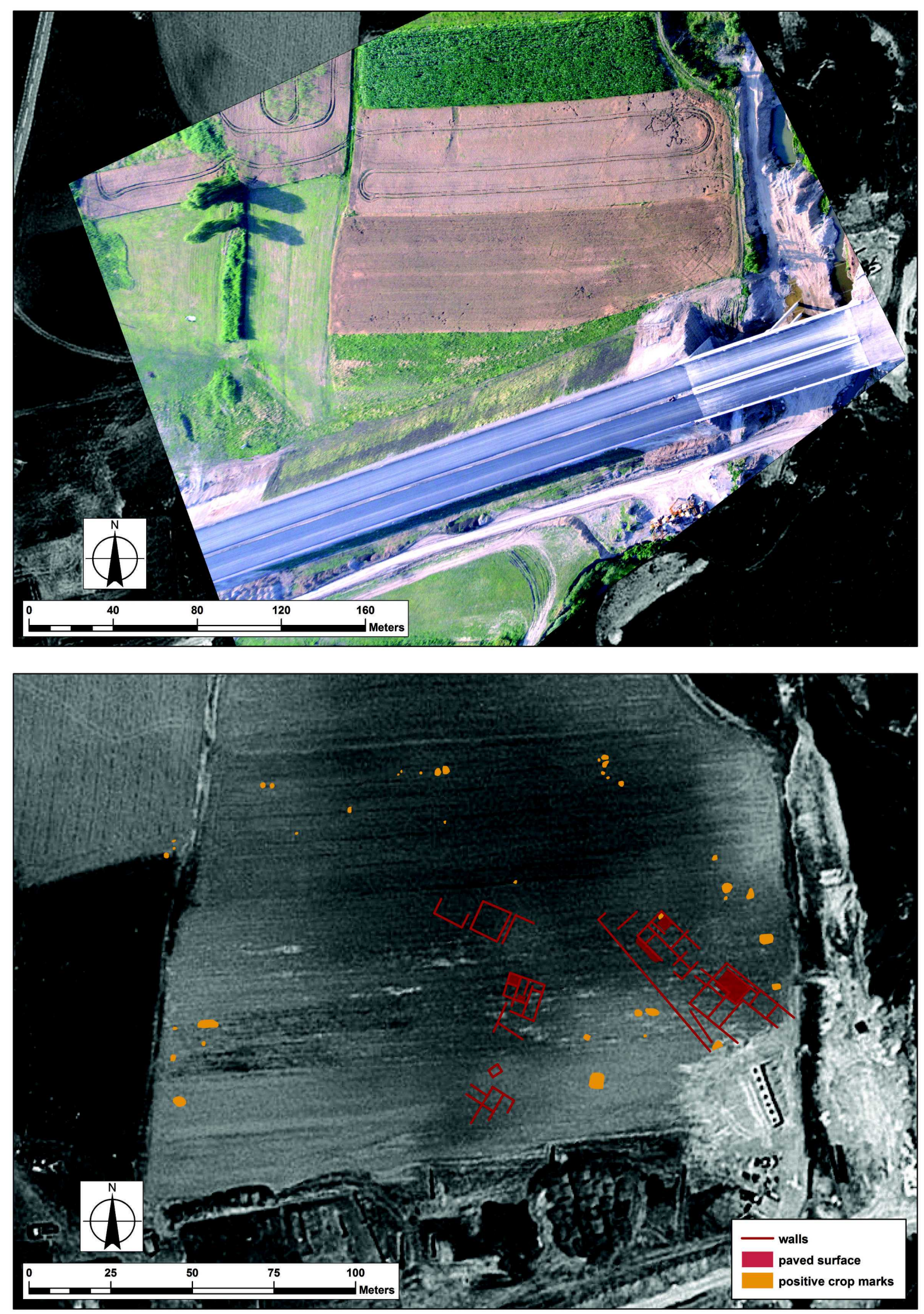

Fig. 14. Positive and negative growth anomalies south to Sibişeni, north to the motorway (Photo: Z. Czajlik, 2nd-3rd July 2013; interpretation (using GE-imagery): L. Rupnik, May 2014). 


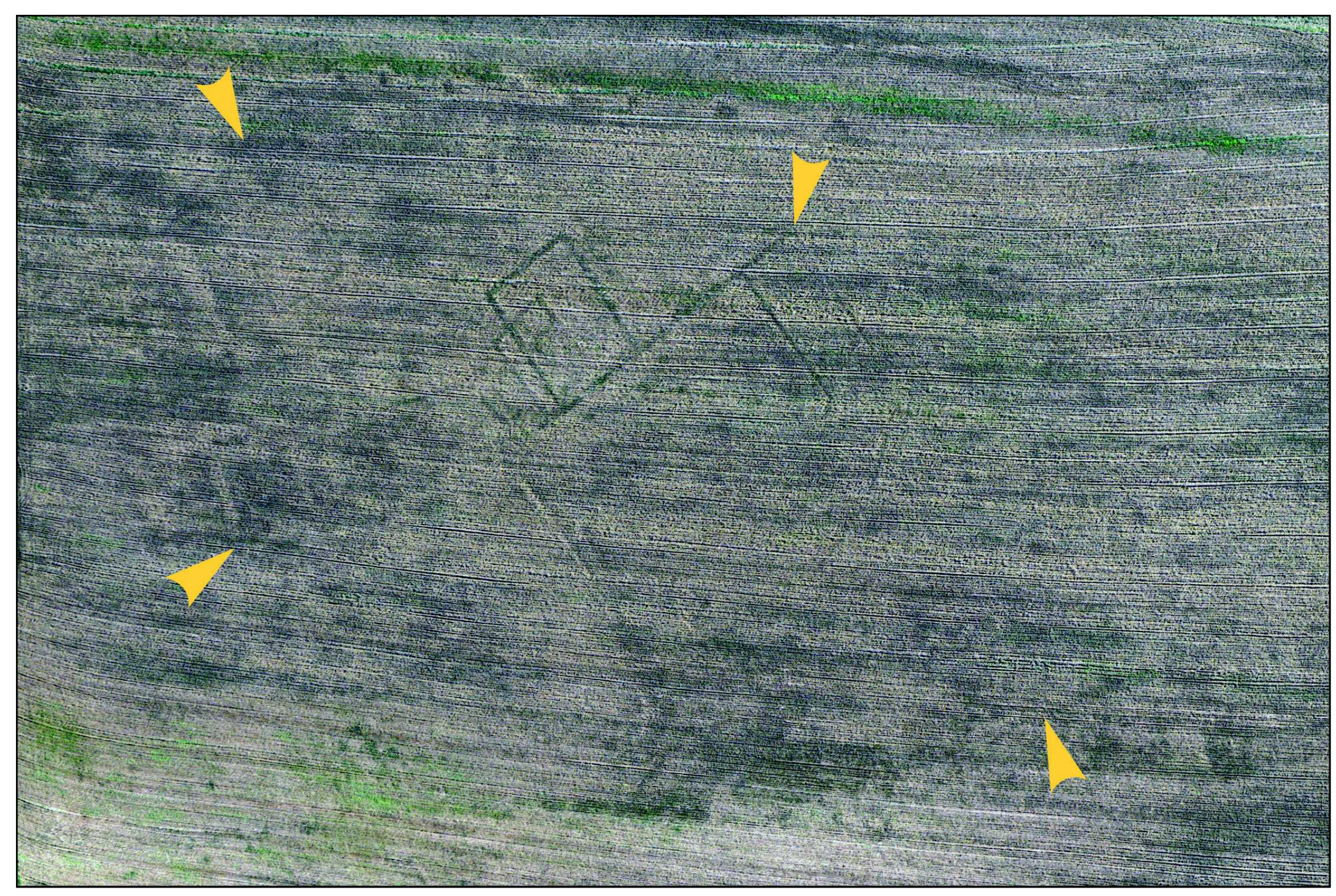

Fig. 15. Roman(?) buildings in the vicinity of Oarda (Photo: Z. Czajlik, 3rd-4th July 2013). 


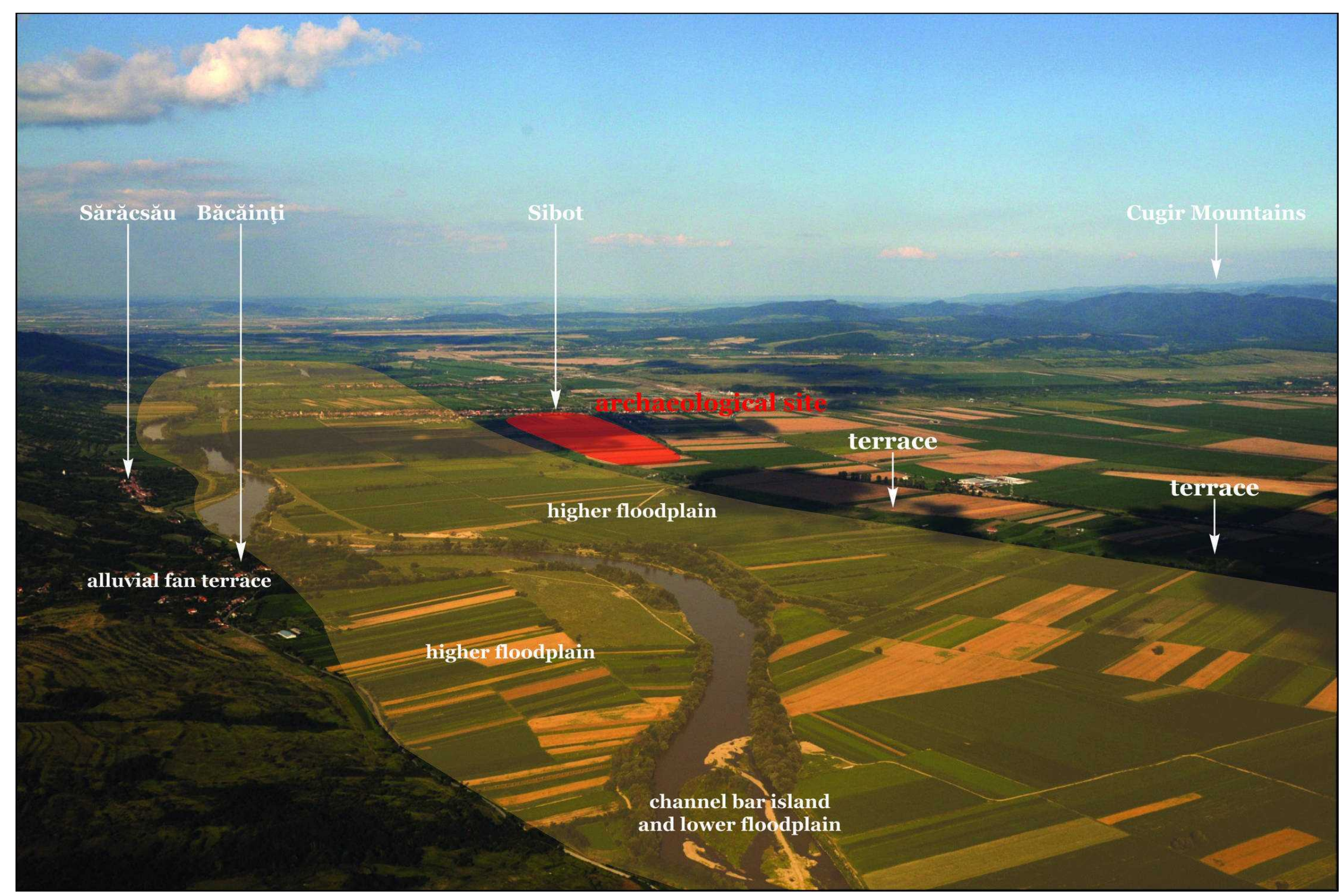

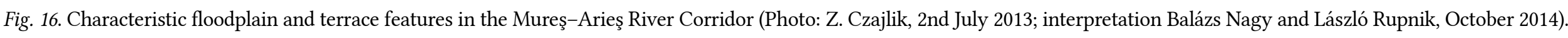




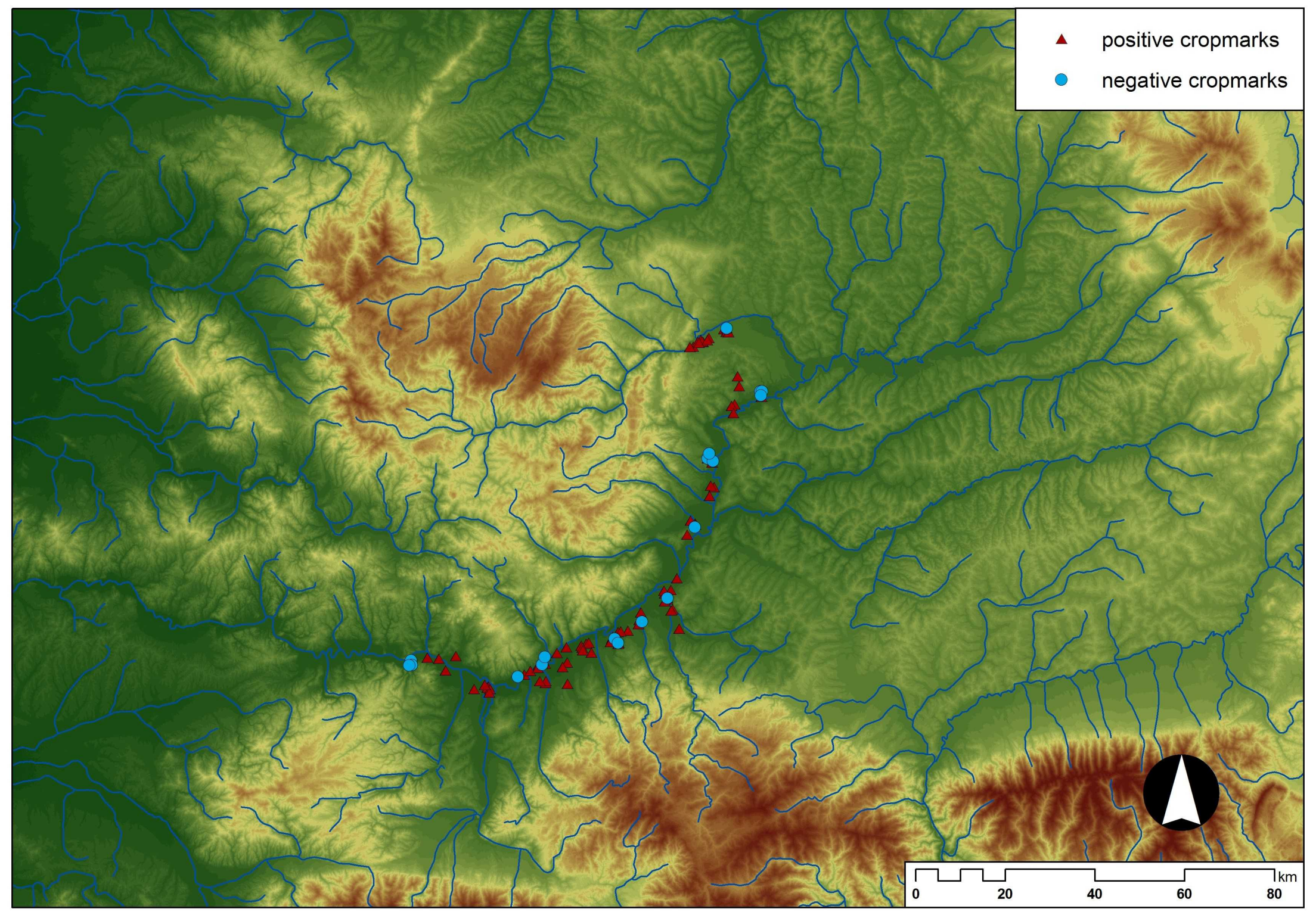

Fig. 17. Archaeological sites identified in 2013 based on the crop marks from the Mureş-Arieş River Corridor (L. Rupnik, May 2014). 